\title{
Measuring the sustainability of wood consumption at the household level in Indonesia: Case study in Bogor, Indonesia
}

\author{
LUTFY ABDULAH ${ }^{1,2, \boldsymbol{v}}$, ENDANG SUHENDANG ${ }^{2}$, HERRY PURNOMO $^{2}$, JUANG R. MATANGARAN $^{2}$ \\ ${ }^{1}$ Forest Research and Development Agency, Forest Research, Development and Innovation Agency. Jl. Gunung Batu No. 5, Bogor 16118, West Java, \\ Indonesia \\ ${ }^{2}$ Program of Forest Management, Graduate School, Institut Pertanian Bogor. Jl. Lingkar Akademik, Kampus IPB Darmaga, Bogor 16980, West Java, \\ Indonesia. Tel.: +62-251-8621244, Fax.: +62-251-8626265, `email: manhut@ipb.ac.id; lutfyabdulah@ yahoo.co.id
}

Manuscript received: 27 September 2019. Revision accepted: 7 December 2019.

\begin{abstract}
Abdulah L, Suhendang E, Purnomo H, Mattangaran JR. 2020. Measuring the sustainability of wood consumption at the household level in Indonesia: Case study in Bogor, Indonesia. Biodiversitas 21: 457-464. Data on consumption of wood products at the end-user level does not yet exist. This is caused by variations in the shape of wood products and raw materials used. Meanwhile, information on the level of consumption per capita is needed to measure sustainability consumption at the household level, de termine the volume of wood production and carbon storage in wood products in the household. The novelty of this study is in method for measure wood product consumption. The aim of this study was to estimate the level of wood consumption at the household level in the form of use for construction and furniture. The method used was a survey of wood products at the industrial level and to make a database and then confirmed to households to determine the level of consumption. The results showed that wood products in the household are divided into 2 main parts namely construction and furniture. The level of wood consumption varied greatly depending on the type of roof, the number of doors and windows and the amount of furniture used. The level of consumption in Bogor reached $0.1 \mathrm{~m}^{3}$ per capita. This consumption was influenced by the time of use and the size of family.
\end{abstract}

Keywords: Database, household, products, volume, wood consumption

\section{INTRODUCTION}

Sustainable wood consumption is a global concern to reduce pressure on forest sustainability. This consumption pattern can be in the form of cascade consumption and recycle used wood into new products or panel wood products (Thonemann and Schumann 2018). However, this action cannot be easily accepted because timber harvesting will provide income for communities around the forest and primary forest product industries. Or in other words, it will reduce the value of forests for the community (Roe and Elliott 2006) so that conversion of forests to non-forests will continue.

Forest management continues to be developed with various innovations such as the promotion of wood utilization. Promotion must be supported by the use of fastgrowing species, building forests on a smaller scale, encouraging the development of plantations on non-tree land, encouraging investment in the timber industry sector and making certification of land and forest products as guarantees of sustainable forest management (Adams 2009) although still traditional (Crow et al. 2006) because using wood actually removes carbon uptake (Imhoff et al. 2004).

Several studies have been carried out to measure the environmental impact of the use of wood products (Hashimoto and Moriguchi 2004; Suter et al. 2017; Kayo et al. 2018; Bais-Moleman et al. 2018). Increased production of wood has a positive impact on the improvement of the global and national economy which is characterized by increasing national income (Chen et al. 2015; Kayo et al. 2015; Howard et al. 2016; Tian et al. 2017). For this reason, wood consumption can be maintained through improvements in forest productivity and the forest product processing industry (Crow et al. 2006; Buongiorno 2009; Eastin and Sasatani 2014).

Unfortunately, the scale of research is still global, national and industrial levels. The aspects seen are environment and economy and technology. The impact is that global, national and industrial-scale measurements cannot detect the end-user and the direction of use of the wood itself. The end-user must be a household. For this reason, this study would like to present a method for estimating wood consumption at the household level. This method combines some basic research related to the volume of wood both solid and composite woods. This is the novelty of this research.

Measuring the level of consumption in end users is still limited. This is because measuring the level of consumption on a household scale is not easy (Hsiang et al. 2017). Although it is difficult, it can be done through understanding the characteristics of the product (Wenker et al. 2017) and also the proportion of its use (Kayo et al. 2018). The characteristics of wood products can be approached by considering the conversion factor of the use of wood that has been built so far as stated by Briggs (1994) and Husch et al. (2003).

For this reason, this research was conducted to measure the level of wood consumption in the household sector. To achieve the main goal of research then there are some 
support destinations such as inventory method of consumption at the household level, especially in the construction and home furnishings, inventory data analysis methods and estimation of factors related to the level of wood consumption.

\section{MATERIALS AND METHODS}

\section{Study area}

The tools used in this study were digital set of scale, weight with a maximum capacity of $200 \mathrm{~kg}$, length measuring instruments, writing instruments as well as GPS and cameras. While the material used was wood specific gravity data and basic information on wood products used for the construction of houses and furniture. Other materials used in this study were database software such as XAMPP and PHPRunner to run web-based systems. The study was conducted in the Bogor City and Bogor District. The study was divided into 2 stages, namely the inventory of wood products at the industrial level and interviews on the use of wood products at the household level. Bogor is part of West Java Province which is divided into 2 administrative regions namely Bogor District and Bogor City (Figure 1). The total population of these two regions is 6.8 million people (BPS Provinsi Jawa Barat 2018, 2019) or $2.6 \%$ of Indonesia's population in 2018 (BPS 2019).

\section{Procedures}

The study began with a survey of the weight of both solid wood and panel products (Figure 2). Weight measurements of solid wood products are carried out in furniture and furniture workshops. We carried out the research in 10 furniture industries and timber traders. Each product was weighed and photographed and asked for the type of wood and the dry conditions of its raw materials.
Meanwhile, panel wood products were downloaded on various internet sites that provide this data.

For roof construction, the study began with interviews with field practitioners who built houses. Interviews included the size of the wood and the type of wood used on various roof types. Our respondents were 40 households spread across Bogor District and Bogor City.

Figure 2 shows the class of wood product categories. For furniture such as chairs, tables, beds and cabinets are divided into types of wood raw materials used, namely solid wood and composite wood as explained by Luppold (1987). The measured wood products are then recorded in a web-based database system. The data that has been collected becomes the initial data to be surveyed for use in the household. The research stages are presented in the following Figure 3.

\section{Data analysis}

Assumptions and standardization of values were distinguished based on criteria for use in construction. The criteria were divided into 3 namely (i) roof construction, and (ii) construction of building components and (iii) furniture. The assumption used in the upper construction was an inverted V-shaped roof. In addition, the type of roof used can be either zinc or asbestos and tile. In calculating the number of trees, a constant simulation was made as a coefficient of tree use. The coefficient of tree used for zincbased roofing types was 0.01 and tile was 0.03 . This coefficient applied generally to all home sizes. Meanwhile, the roof size coefficient was the area of the house plus 8.56. The stages of data analysis are as follows:

Roof construction. To determine the volume of the wood used in the roof, this the equation was used:

$$
\left.V_{\text {roof }}=(\text { home area }+8.56) * \text { coofficient of tree } * 0.5 \ldots . .1\right)
$$

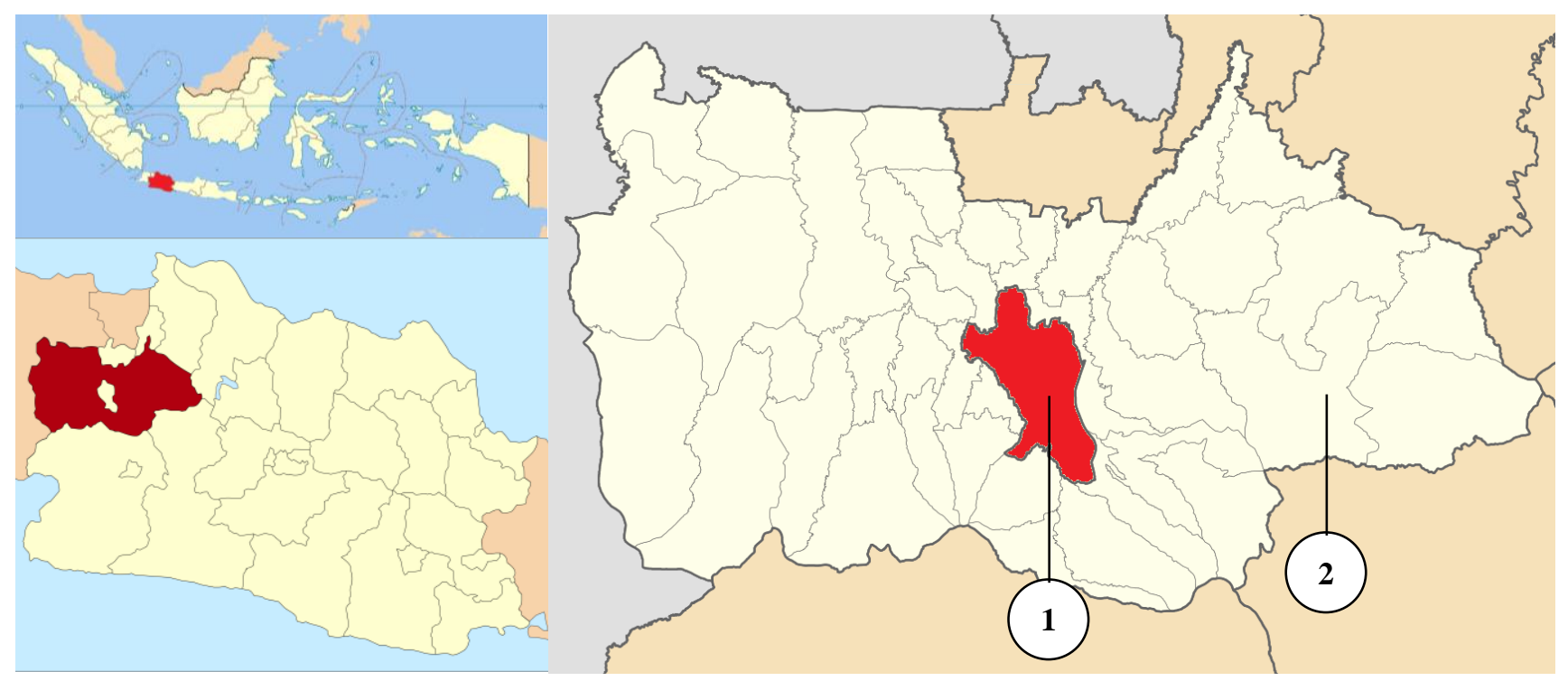

Figure 1. Location of research area in Bogor City (1) and Bogor District (2), West Java, Indonesia 


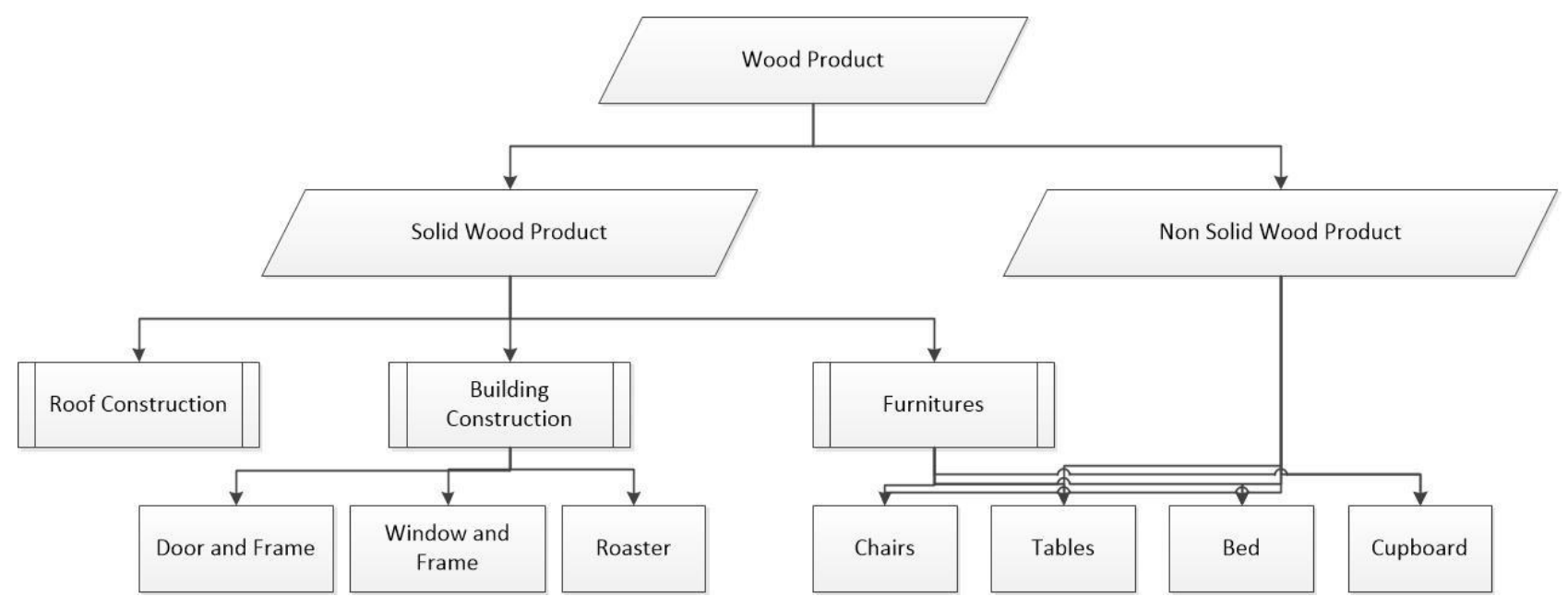

Figure 2. Classification of wood products in households

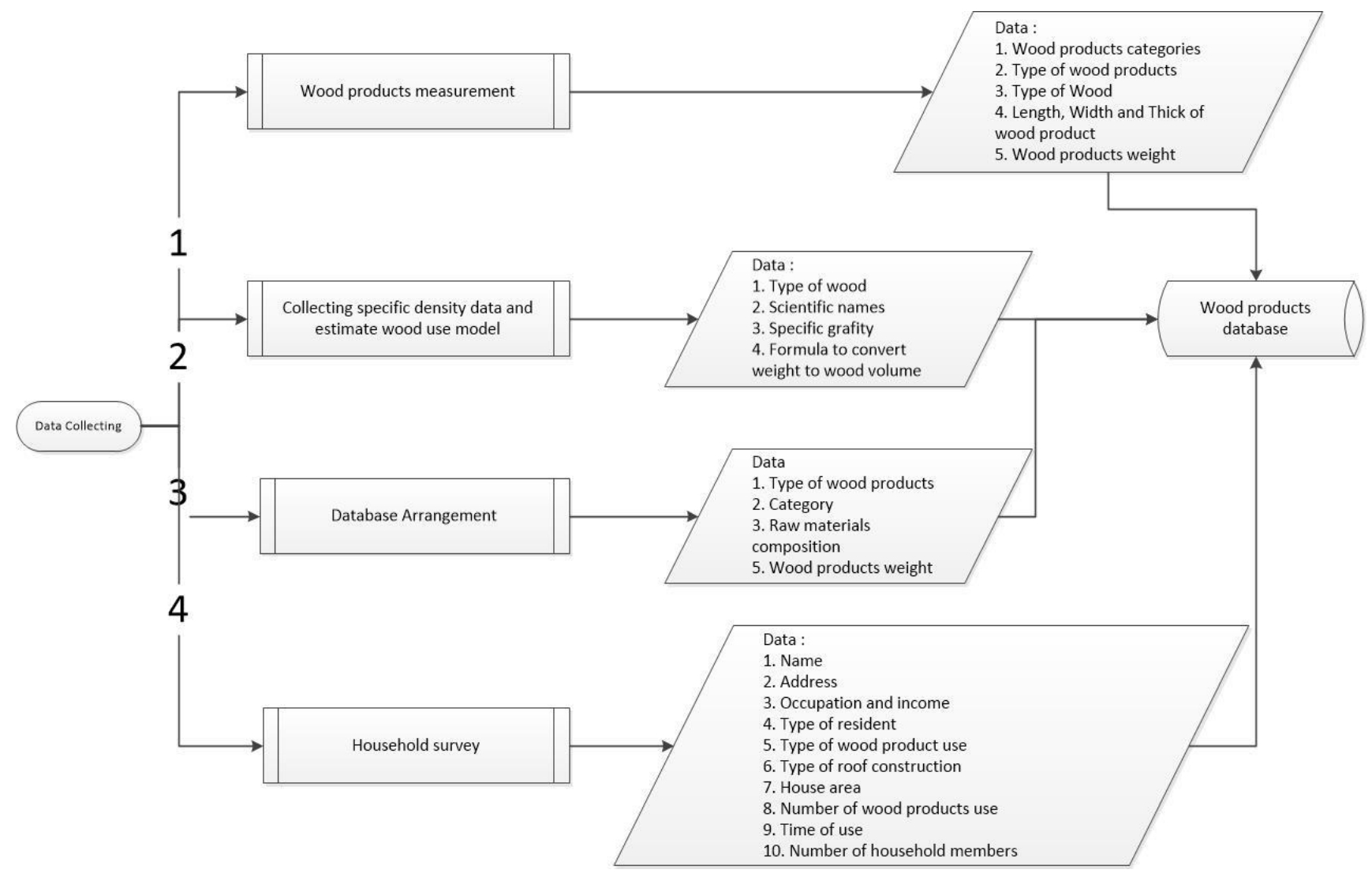

Figure 3. Data collection procedures

Construction of the building and furniture. The two products distinguished by the type of raw material, namely solid wood or composite wood. Volume for solid wood (Briggs 1994):

$$
\mathrm{V}_{\mathrm{obj}}=\left(\frac{\text { Weight of product }}{\text { specific density } \mathrm{x} \text { density of } \mathrm{H}_{2} \mathrm{O} \times \mathrm{M}_{\mathrm{COD} / 100}}\right)
$$

To use equation (2), we assumed the specific density of all wood was 0.48 (Briggs 1994); USDA Forest Service (2010). Specific gravity is the weight per unit (Briggs 1994; USDA Forest Service 2010). While the density of $\mathrm{H}_{2} \mathrm{O}$ was $1000 \mathrm{~kg} . \mathrm{m}^{-3}$ and $\mathrm{M}_{\mathrm{COD}}$ was $12 \%$ (Briggs 1994). Equation (2) was modified by assuming that $90 \%$ of tree volume is used for solid wood products (Kayo et al. 2018). For this reason, this equation can be written: 


$$
\begin{aligned}
& V_{\mathrm{obj}, \mathrm{s}}=\left(\frac{\text { weight of product (kg) }}{0,48 \times 1000 \times 12 / 100}\right) \times 0.9 \\
& V_{\mathrm{obj}, \mathrm{s}}=\left(\frac{\frac{\text { berat obyek }}{2000}}{57.6}\right) \times 0.9 \ldots \ldots \ldots \ldots \ldots \ldots \ldots \ldots \ldots
\end{aligned}
$$

Volume of composite wood products was calculated using the following equation:

$$
V_{\text {objec }}=\left(\frac{\text { Weight of product }}{\text { specifie density } \mathrm{x} \text { density of } \mathrm{H}_{2} \mathrm{O} \times \mathrm{M}_{\mathrm{een}} / 100}\right)
$$

Or could be transformed to:

$$
V_{\text {objns }}=\left(\frac{\text { weĩght of product }}{48}\right) \times 0.1
$$

The specific gravity for particle board and/or wood composites ranged from 0.6 to 0.8 , while $\mathrm{M}_{\mathrm{COD}}$ ranged from 6-9\% (Rowell 2014). For this study, we used a specific gravity of 0.8 and $\mathrm{M}_{\mathrm{COD}}$ of $6 \%$.

Per capita consumption can be calculated using the formula:

$$
\text { Consumtion }=\frac{\frac{v_{\text {roof }}}{\text { time ofroofuse }}+\sum_{i=L \text { time }}^{n}+\sum_{i=1}^{n} \frac{v_{f}}{\text { nime }}}{\text { number of family members }}
$$

\section{RESULTS AND DISCUSSION}

\section{The weight of wood products}

The weight of solid wood products is greater than that of composite wood (Figure 4). But for table weight, the average weight of composite products is greater. This might be caused by additional materials used in this product in the form of iron, aluminum or other. There are some research errors such as (i) the type of wood used in one product is not the same, (ii) some wood products have not been painted and some have been painted (iii), in some sample products used glass, plastic and even wood panels. However, the proportion of its use was very small. For this reason, we assume that the type of wood used was the dominant type of wood in the product, while the condition of the product being painted and other additives were ignored.

\section{Wood in roof construction}

The use of wood for roofing instructions is usually distinguished by the type of roof used as asbestos/tin or tile roofs. Usually, people choose one of these types of roofs. However, there are some who combine it. This depends on the allocation and availability of funds. Figure 5 shows that there are differences in the use of wood volume from these two types of roofs. Roof tiles use 4 layers of wood, while tin roofs only 2 layers of wood (Table 1).

In general, Bogor residents use tile compared to asbestos/tin. The need for wood to make a house roof ranged from $0.008 \mathrm{~m}^{3} . \mathrm{m}^{-2}$ to $0.016 \mathrm{~m}^{3} . \mathrm{m}^{-2}$. If the type of roof used is tile, it needs 0.01 to $0.021 \mathrm{~m}^{3} . \mathrm{m}^{-2}$, while if the type of roof used is asbestos is $0.005-0.01 \mathrm{~m}^{3} . \mathrm{m}^{-2}$. This means that in constructing a roof made of wood, the minimum amount of wood needed is $0.008 \mathrm{~m}^{3} . \mathrm{m}^{-2}$.

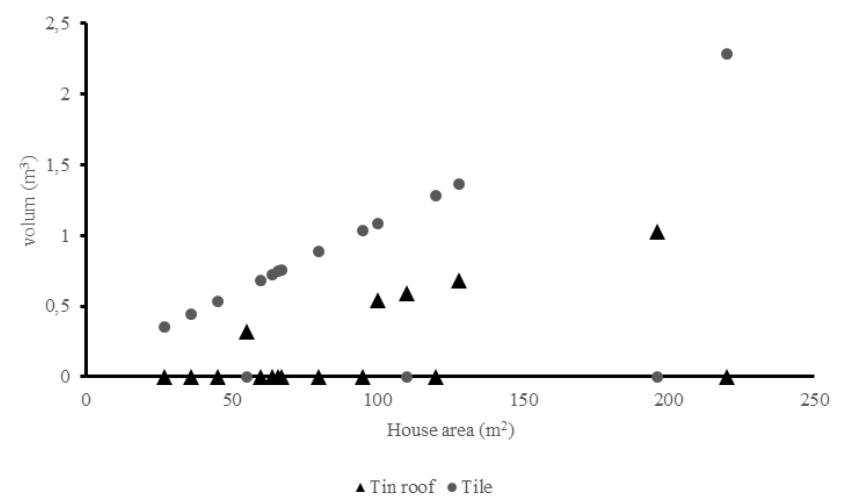

Figure 5. Wood volume in roof

Table 1. Wood used in roof area $\left(\mathrm{m}^{3} . \mathrm{m}^{-2}\right)$

\begin{tabular}{lccc}
\hline \multirow{2}{*}{ Type of roof } & \multicolumn{3}{c}{ Wood volume $\left(\mathbf{m}^{\mathbf{3}} \cdot \mathbf{~ m}^{-2}\right)$} \\
\cline { 2 - 4 } & Average & Min & Max \\
\hline Tin & 0.006 & 0.005 & 0.011 \\
Tile & 0.012 & 0.010 & 0.021 \\
Average & 0.009 & 0.008 & 0.016 \\
\hline
\end{tabular}

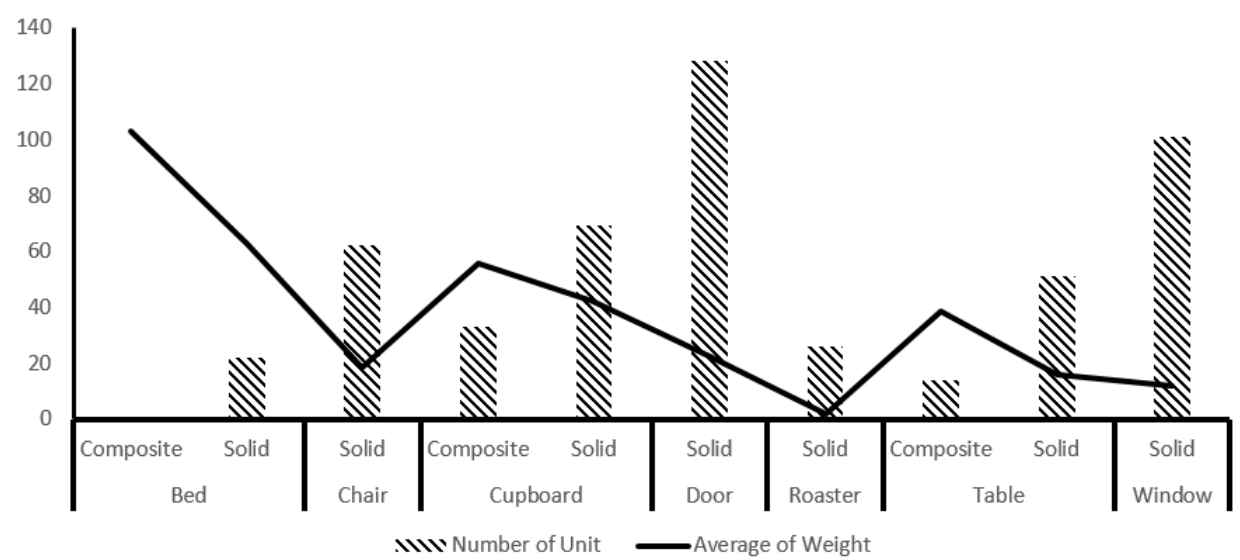

Figure 4. Wood products number and weight from survey 


\section{Use of wood in building construction}

Building construction consists of doors, windows, and roasters. In general, the type of wood raw material used was solid wood. However, some people used plywood as a door leaf. A healthy home will consist of these three components. For this reason, the need for wood to build this component ranged from 0.0035 to $0.13 \mathrm{~m}^{3} . \mathrm{m}^{-2}$ with a deviation of $0.03 \mathrm{~m}^{3} . \mathrm{m}^{-2}$. This means that in constructing 1 $\mathrm{m}^{2}$ of houses, it requires at least $0.004 \mathrm{~m}^{3} \cdot \mathrm{m}^{-2}$ or $0.4 \mathrm{~m}^{3}$ for $100 \mathrm{~m}^{2}$ of house area (Table 2).

\section{The use of wood for home furnishings}

Household furniture usually consists of chairs, tables, cabinets, sofas, and beds (Table 3). However, not all houses use all this furniture. This depends on the area of the house and income and the type of wood raw material used. Types of raw materials consist of solid wood and composite wood.

The chairs and sofas are always made of solid wood. To make a chair requires $0.05-2.13 \mathrm{~m}^{3}$ of wood. Meanwhile, to make cabinets made from solid wood it takes $0.18-3.12 \mathrm{~m}^{3}$ or composite raw materials as much as $0.01-0.67 \mathrm{~m}^{3}$, more than using composite wood. Cabinets can be made of solid wood or composite wood. In addition, cabinets can be made of composite wood and solid wood.

\section{Total wood usage}

The above description shows measuring the level of use of wood is very dependent on components in construction (roof construction, building construction, and furniture). The average use of wood in building houses (roof and building construction) was $0.03 \mathrm{~m}^{3} . \mathrm{m}^{-2}$. While for furniture, the demand depends on the needs.

Table 4 illustrates the need for wood to build a house where there is a roof and building construction. Roof tile roof construction requires $0.014-0.15 \mathrm{~m}^{3} \cdot \mathrm{m}^{-2}$ building area. While the construction of zinc-roofed buildings required as much as $0.009-0.14 \mathrm{~m}^{3} . \mathrm{m}^{-2}$ building area. These figures show that the difference in wood demand is not significant. While the use of solid wood-based household furniture will encourage more wood usage than composite wood-based furniture. The average wood demand for furniture made from solid wood reached $4.7 \mathrm{~m}^{3}$, while for furniture made from composite wood it reached $0.5 \mathrm{~m}^{3}$.

Cabinets and beds need more wood. To make cabinets need $0.2 \mathrm{~m}^{3}$ of solid wood or $0.05 \mathrm{~m}^{3}$ of composite wood. While the bed requires a minimum of $0.9 \mathrm{~m}^{3}$ of solid wood or $0.21 \mathrm{~m}^{3}$ of composite wood (Table 5 ).

\section{Per capita wood consumption}

Wood consumption per capita is a measure of the time of use of a wood product per person, expressed in a period of one year. Consumption is greatly influenced by the type of wood product. Timber consumption in this study was limited to sawn timber and industrial wood, while fuelwood, paper, and other wood products were not considered (Table 6).

Table 2. Wood used in building construction $\left(\mathrm{m}^{3} \cdot \mathrm{m}^{-2}\right)$

\begin{tabular}{lcccc}
\hline Component of & \multicolumn{4}{c}{ Wood volume $\left(\mathbf{m}^{\mathbf{3}} \cdot \mathbf{~ m}^{-\mathbf{2}}\right)$} \\
\cline { 2 - 5 } construction & Average & Min & Max & Deviation \\
\hline Window & 0.0073 & 0.0012 & 0.0259 & 0.0056 \\
Door & 0.0104 & 0.0023 & 0.0332 & 0.0069 \\
Roaster & 0.0054 & 0.0001 & 0.0675 & 0.0135 \\
Total & 0.0232 & 0.0035 & 0.1266 & 0.260 \\
\hline
\end{tabular}

Table 4. Demand for wood for construction

\begin{tabular}{lccc}
\hline \multirow{2}{*}{ Tipe of roof } & \multicolumn{3}{c}{ Wood volume $\left(\mathbf{m}^{\mathbf{3}} \cdot \mathbf{~ m}^{-\mathbf{2}}\right)$} \\
\cline { 2 - 4 } & Average & Min & Max \\
\hline Asbestos/tin & 0.006 & 0.005 & 0.011 \\
Tile & 0.012 & 0.010 & 0.021 \\
Window & 0.007 & 0.001 & 0.026 \\
Door & 0.010 & 0.002 & 0.033 \\
Roaster & 0.005 & 0.000 & 0.068 \\
Total for asbestos/tin & 0.030 & 0.009 & 0.137 \\
Total for tile & 0.035 & 0.014 & 0.148 \\
\hline
\end{tabular}

Table 5. Wood demand for home furnishings

\begin{tabular}{lccc}
\hline \multirow{2}{*}{ Furniture } & \multicolumn{3}{c}{ Wood volume $\left(\mathbf{m}^{3}\right)$} \\
\cline { 2 - 4 } & Average & Min & Max \\
\hline Composite wood-based $\left(\mathrm{m}^{3}\right)$ & & & \\
$\quad$ Chair & & & \\
Cabinet & 0.16 & 0.01 & 0.67 \\
Table & 0.10 & 0.05 & 0.29 \\
Bed & 0.21 & 0.21 & 0.21 \\
Total & 0.47 & 0.27 & 1.17 \\
Solid wood-based $\left(\mathrm{m}^{3}\right)$ & & & \\
$\quad$ Chair & 0.64 & 0.05 & 2.13 \\
Cabinet & 0.81 & 0.18 & 3.12 \\
Table & 0.28 & 0.07 & 0.10 \\
Bed & 1.30 & 0.86 & 3.86 \\
Total & 4.67 & 1.52 & 14.00 \\
\hline
\end{tabular}

Table 3. Wood use in furniture

\begin{tabular}{|c|c|c|c|c|c|c|c|c|}
\hline \multirow{3}{*}{ Furniture } & \multicolumn{8}{|c|}{ Wood volume $\left(\mathbf{m}^{3}\right)$} \\
\hline & \multicolumn{4}{|c|}{ Composite } & \multicolumn{4}{|c|}{ Solid } \\
\hline & Average & Min & Max & Deviation & Average & Min & Max & Deviation \\
\hline Chair & - & - & - & - & 0.639 & 0.050 & 2.130 & 0.481 \\
\hline Cabinet & 0.164 & 0.010 & 0.670 & 0.146 & 0.814 & 0.180 & 3.120 & 0.561 \\
\hline Table & 0.098 & 0.050 & 0.290 & 0.059 & 0.275 & 0.070 & 0.890 & 0.126 \\
\hline Bed & 0.210 & 0.210 & 0.210 & - & 1.302 & 0.860 & 3.860 & 0.724 \\
\hline Sofa & & & & & 1.639 & 0.360 & 3.980 & 1.250 \\
\hline
\end{tabular}


Table 7. Correlation test

\begin{tabular}{llccccc}
\hline & & $\begin{array}{c}\text { Per capita wood } \\
\text { consumption }\end{array}$ & Time of use & $\begin{array}{c}\text { Family } \\
\text { members }\end{array}$ & $\begin{array}{c}\text { Income } \\
\left.(\text { IDR. month })^{-1}\right)\end{array}$ & $\begin{array}{c}\text { Building area } \\
\left(\mathbf{m}^{\mathbf{2}}\right)\end{array}$ \\
\hline Per capita wood & Pearson correlation & 1 & $-.139^{* *}$ & $-.197^{* *}$ & -.023 & .003 \\
consumption & Sig. (2-tailed) & & .001 & .000 & .594 & .938 \\
& $\mathrm{~N}$ & 536 & 536 & 536 & 536 & 536 \\
\hline
\end{tabular}

Table 6. per capita consumption in household

\begin{tabular}{lccc}
\hline Type of use & \multicolumn{2}{c}{ Type of wood-base } & \multirow{2}{*}{ Total } \\
\cline { 2 - 3 } & Composite & Solid & \\
\hline Roof & & 0.02 & 0.02 \\
Building construction & & 0.04 & 0.04 \\
Furniture & 0.01 & 0.03 & 0.04 \\
Sum & 0.01 & 0.09 & 0.1 \\
\hline
\end{tabular}

The level of wood consumption for the roof was $0.2 \mathrm{~m}^{3}$ person $^{-1}$ year $^{-1}$. Meanwhile, the level of wood consumption for building construction reached $0.04 \mathrm{~m}^{3}$ person $^{-1}$ year ${ }^{-1}$. The level of wood consumption for furniture from composite wood and solid wood, respectively, was $0.01 \mathrm{~m}^{3}$ person $^{-1}$ year $^{-1}$ and $0.03 \mathrm{~m}^{3}$ person $^{-1}$ year $^{-1}$. In general, the level of household wood consumption for construction and furniture reached $0.1 \mathrm{~m}^{3}$ person $^{-1}$ year $^{-1}$. Per capita consumption can be converted into units of use to one housing unit (roof, building construction, and furniture). If all building materials and furniture used solid wood, the consumption level will reach $0.09 \mathrm{~m}^{3}$ person $^{-1}$ year $^{-1}$. Meanwhile, if the roof and building construction use solid wood while the furniture is composite wood, the consumption level will reach $0.07 \mathrm{~m}^{3}$ person $^{-1}$ year $^{-1}$. This shows that wood consumption will increase if the raw material for wood products is solid wood.

Per capita, wood consumption is strongly influenced by the time it takes for someone to use the wood product and the number of family members. This was indicated by the very strong correlation between time of use and number of family members with the level of consumption per capita (Table 7).

There was a negative correlation between the age of use and the level of consumption per capita. This shows that the use of wood at home is very dependent on the condition of the wood product. If the product has experienced weathering, the wood product will be replaced with a more durable substitute item. In addition, the number of family members in the family also influenced the level of consumption, especially in the use of furniture. This information shows that to maintain the level of consumption it is necessary to improve the quality of wood and household units that use wood products.

\section{Discussion}

Measurement of the level of per capita wood consumption can be used as a database to measure the level of community preference for using wood products or community efforts to store carbon at home, even though the community is not aware of it. This effort is a community effort to reduce the impact of emissions produced by households. The use of this database can reduce uncertainty when compared to databases at the national and regional levels (Buongiorno 2009; Rodrigues et al. 2018).

The results of this study indicate that there are 3 locations for the use of wood in households, namely the roof, buildings, and household furniture. Household furniture contributed higher per capita consumption compared to roofs and buildings. This contribution came from the quality of the wood used for better furniture and its use is not in direct contact with rain and open land. While the roof will often be replaced because the type of wood used is wood with low quality. The use of highquality wood can not be surrendered to the market mechanism alone. There is a need for encouragement from the industrial sector through changing mental models in producing solid wood so that the wood can be used for a long time (Hildebrandt et al. 2017). Changes in mental models include technological reform, knowledge, wider application of technology, financing and also subsidies from the government.

The results of this study found that the level of wood consumption in a household was very dependent on the time of use and the number of family members. The time of use is related to the time of use until the wood product is damaged. While the number of family members is related to the number of people who take part in consuming wood products in one house. These study results are in line with the results of research by Tian et al. (2017).

The results of this study found that the level of wood consumption per capita for construction wood and furniture in Indonesia reached $0.1 \mathrm{~m}^{3}$ per capita. This figure is close to the level of wood consumption in the United States which reached $1.26 \mathrm{~m}^{3}$ per capita (Howard and Jones 2016). They were calculated the consumption of wood products in the United States of all derivative products such as wood for construction, furniture, and paper.

This research is able to produce a mechanism for collecting and analyzing data related to wood consumption. Data on wood consumption is available in 2 scales, namely national and industrial scales. It is suspected that final consumption is still constrained (Spelter and McKeever 1978). Although there are still several assumptions that must be met in measuring the level of consumption in a household, it is necessary to determine the proportion of wood products in a tree. For solid wood, it reached $90 \%$ and the rest was composite wood. This is based on the results of research by Araya and Katsuhisa (2008) which stated that the use of wood for construction is dominated by solid wood. Another assumption used is the specific density of all types of wood that is equal to 0.48 . This 
assumption is used because in one wood product there is more than one type of tree. In addition to these assumptions, the next assumption is that the weight of the products contained in both solid wood and composite wood is heavy wood. As for there are complementary materials are ignored. This assumption is made because the proportion of the weight of complementary goods is not more than $1 / 2$ the weight of the wood product.

This research was built from combining data collected in industry and then verifying its use at the household level. This step was done by building a database system. Unfortunately, the collection of wood products is still limited. This is caused by wood furniture products in Indonesia are very diverse. The diversity of Indonesian furniture products due to the nature of community use is more vernacular architecture (Forshee 2006).

Information on consumption levels will have an impact on global forest growth. Bais et al. (2015) predicted that the rate of forest productivity would increase by $7 \%$, with a forest growth rate of $0.2 \%$. Efforts to increase timber consumption per capita will result in forest and environmental damage (Howard and Jones 2016). This opinion is disputed by Kim et al. (2018). They argued that increasing per capita wood consumption will slow forest conversion. This can happen if this business is more profitable than other businesses. Every $10 \%$ increase in prices will encourage $0.08 \%$ replanting of forests. Conversely, if the price of wood falls by $10 \%$, the area of forested area will decrease by $0.09 \%$.

Efforts to increase the level of wood consumption can be done by ensuring stable wood prices, sustainable wood products according to biophysical carrying capacity, clear rights to forests and supported by correct timber administration institutions, forest governance, good harvesting, and wood processing infrastructure (Naumov et al. 2016). The implementation of this strategy is expected to reduce poverty (Mitlin and Satterthwaite 2004). Thus, to increase timber consumption, an integrated management system must be seen. Sustainable timber harvesting and in accordance with ecological carrying capacity, appropriate prices, application of innovative technology, recognition of land rights and public infrastructure that can be enjoyed by all levels of society, especially around the forest. We argue that to increase wood consumption departs from increasing national income (Drummond 2015; Kayo et al. 2015; Koebel et al. 2016) and followed by the implementation of strategies above. Good wood quality will encourage wood prices to go up, so an increase in GDP will make it easier for people to buy wood products (Gaston 1997).

Developing countries tend to use composite wood instead of solid wood because of low GDP (Kayo et al. 2015), while the community must add development costs by $18-50 \%$ of the total cost of buying wood (Luppold 1987; Elling and Mckeever 2018). GDP can be boosted by increasing exports (Tian et al. 2017). Of course, exports will be carried out if wood production is high and local needs are met. Countries with low GDP conditions will continue to extract wood and then face acute environmental damage problems (Chaudhary et al. 2017) while they use composite wood produced by countries with high GDP levels. This condition makes developing countries tend to have emission levels reaching 100-1000 times greater than developed countries (Chaudhary et al. 2017) because they move carbon from forests in large quantities and store carbon in the form of low wood products. This is because using composite wood can increase emissions by $8 \%$ compared to using solid wood (Kayo et al. 2015). In other words, the use of solid wood can be an indicator of community welfare.

Wood consumption can be met by increasing the productivity of plantations. This will have an impact on economic improvement and also reduce $\mathrm{CO}_{2}$ emissions by $53.74 \mathrm{~kg} \mathrm{CO}_{2}$ eq m${ }^{-2}$ (Potkány et al. 2018). This innovation can be subsidized through low taxation thereby reducing production costs (Hildebrandt et al. 2017). This data shows that in terms of maintaining carbon storage it is necessary to use more solid wood and produce composite wood with more environmentally friendly technology. In order for the level of consumption of solid wood to increase, it is necessary to innovate in improving the quality of wood (Potkány et al. 2018. Composite wood production must also use new and renewable energy so that emissions are low (Kazulis et al. 2017).

In conclusion, the results of this study proved that the use of a database of wood products collected in the wood processing industry and verification of use at the household level can provide data on per capita wood consumption. Measurement of the level of wood consumption in households was divided into 3 groups namely overhead construction, construction of building bodies and furniture. Timber demand for roof construction and construction of building bodies sequentially ranged between $0.008 \mathrm{~m}^{3} \cdot \mathrm{m}^{-2-}$ $0.016 \mathrm{~m}^{3} \cdot \mathrm{m}^{-2}$ and $0.0035-0.13 \mathrm{~m}^{3} \cdot \mathrm{m}^{-2}$. While the wood demand for furniture varied greatly depending on product categories and types of raw materials used. The need for wood for roof construction and building bodies ranged from 0.001 to $0.014 \mathrm{~m}^{3} \cdot \mathrm{m}^{-2}$. In general, wood consumption per capita was $0.1 \mathrm{~m}^{3}$. To increase the consumption of wood per capita it is necessary to innovate technology in improving the quality of wood products and the promotion of the use of wood products. This research can be used as a reference inventory of wood usage to measure wood consumption per capita. However, a database of wood products, especially furniture, needs to be added.

\section{ACKNOWLEDGEMENTS}

We thank FORDA, Dr. Krisfianti L. Ginoga, Harbagung, Lisa Adelina, H. Gozali, Rinaldi Imanuddin, Dr. Haruni Krisnawati, Dr. H. Darwo, Mira Yulianti, and all those who have helped in the research process.

\section{REFERENCES}

Adams R. 2009. Forestry and wood products research and promotion move with the times. Aust For 72 (4): 147-148. DOI: 10.1080/23256087.2009.12002191 
Araya A, Katsuhisa H. 2008. Japanese Wood Market And Use Of Tropical Wood. FAO, Rome, Italy.

Bais-Moleman AL, Sikkema, Vis M, Reumerman P, Theurl MC, Erb KH. 2018. Assessing wood use efficiency and greenhouse gas emissions of wood product cascading in the European Union. J Cleaner Prod 172: 3942-3954. DOI: 10.1016/j.jclepro.2017.04.153

Bais ALS, Lauk C, Kastner T, Erb K. 2015. Global patterns and trends of wood harvest and use between 1990 and 2010. Ecol Econ 119: 326337. DOI: 10.1016/j.ecolecon.2015.09.011

BPS. 2019. Statistik Indonesia Tahun 2018. Badan Pusat Statistik, Jakarta. DOI: 10.1192/bjp.111.479.1009-a [Indonesian]

BPS Provinsi Jawa Barat 2018. 2019. Jawa Barat Province in Figures. BPS Provinsi Jawa Barat. BPS, Bandung. DOI: 32560.1802 [Indonesian]

Briggs DG. 1994. Forest product measurements and conversion factors : with special emphasis on the U.S. Pacific Northwest. University of Washington. Institute of Forest Resources, Washington, DC.

Buongiorno J. 2009. International trends in forest products consumption: is there convergence? Int For Rev 11 (4): 490-500. DOI: $10.1039 / \mathrm{c} 7 \mathrm{tb} 00748 \mathrm{e}$

Chaudhary A, Carrasco LR, Kastner T. 2017. Linking national wood consumption with global biodiversity and ecosystem service losses. Sci Total Environ 586: 985-994. DOI 10.1016/j.scitotenv.2017.02.078

Chen W, Xu D, Liu J. 2015. The forest resources input-output model: An application in China. Ecol Indicat 51: 87-97. DOI: 10.1016/j.ecolind.2014.09.007

Crow TR, Dey DC, Riemenschneider D. 2006. Forest productivity: producing goods and services for people. Minnesota.

Drummond RCM. 2015. Understanding demand for wood products in New Zealand's major log markets. [Dissertation]. University of Canterbury, Christchurch, NZ.

Eastin I, Sasatani D. 2014. An Assessment of the Competitive Impact of Japanese Domestic Wood Programs on the Future Demand for US Wood Products in Japan. Working Paper 123. Center for International Trade in Forest Products (CINTRAFOR),University of Washington, Seattle, WA

Elling J, Mckeever DB. 2018. Wood Products Used in Residential Repair and Remodeling in the United States, 2014. Gen. Tech. Rep. FPL GTR-256. U.S. Department of Agriculture, Forest Service, Forest Products Laboratory, Madison, WI.

Forshee J. 2006. Culture and Customs of India. Greenwood Press, Westport, Connecticut, London, UK.

Gaston CW. 1997. An Econometric Analysis of the Demand for Wood Products in Japan by Product Type, Species, and Source, (April), 173

Hashimoto S, Moriguchi Y. 2004. Data Book: Material and Carbon Flow of Harvested Wood in Japan, National Institute for Environmental Studies (NIES), Ibaraki, Japan

Hildebrandt J, Hagemann N, Thrän D. 2017. The contribution of woodbased construction materials for leveraging a low carbon building sector in Europe. Sustain Cities Soc 34: 405-418. DOI 10.1016/j.scs.2017.06.013

Howard JL, Jones KC. 2016. U.S. Timber Production, Trade, Consumption, and Price Statistics, 1965-2013. USDA Forest Service, Forest Products Laboratory, Research Paper FPL-RP-679. U.S. Department of Agriculture, Forest Service, Forest Products Laboratory, Madison, WI.

Howard JL, Mckeever DB, Bilek EMT. 2016. Criterion 6 Indicator 28 Total and Per Capita Consumption of Wood and Wood Products in Roundwood Equivalents, (March). Research Note FPL-RN-0338. U.S. Department of Agriculture, Forest Service, Forest Products Laboratory, Madison, WI.
Hsiang S, Kopp R, Jina A, Rising J, Delgado M, Mohan S, Houser T. 2017. Estimating economic damage from climate change in United States. Science 356: 1362-1369.

Husch B, Beers TW, Kershaw JA. 2003. Forest Mensuration. 4th ed. John Wiley \& Sons, INC, New Jersey.

Imhoff ML, Bounoua L, Ricketts T, Loucks C, Harriss R, Lawrence WT. 2004. Global patterns in human consumption of net primary production. Nature 429: 870-873. DOI: 10.1038 /nature02685

Kayo C, Dente SMR, Aoki-Suzuki C, Tanaka D, Murakami S, Hashimoto S. 2018. Environmental Impact Assessment of Wood Use in Japan through 2050 Using Material Flow Analysis and Life Cycle Assessment. J Ind Ecol 00 (0). DOI: 10.1111/jiec.12766

Kayo C, Oka H, Hashimoto S, Mizukami M, Takagi S. 2015. Socioeconomic development and wood consumption. J For Res 20 (3): 309-320. DOI: 10.1007/s10310-015-0481-6

Kazulis V, Muizniece I, Zihare L, Blumberga D. 2017. Carbon storage in wood products. Energy Procedia 128: 558-563. DOI: 10.1016/j.egypro.2017.09.009

Kim TJ, Wear DN, Coulston J, Li R. 2018. Forest land-use responses to wood product markets. For Policy Econ 93: 45-52. DOI: 10.1016/j.forpol.2018.05.012

Koebel BM, Levet AL, Nguyen-Van P, Purohoo I, Guinard L. 2016. Productivity, resource endowment and trade performance of the wood product sector. J For Econ 22: 24-35. DOI: 10.1016/j.jfe.2015.10.004

Luppold WG. 1987. Material usage trends in the wood household furniture industry. For Serv Res Pap 10p-10p.

Mitlin D, Satterthwaite D. 2004. Participation and Sustainability in Social Projects: The Experience of the Local Development Programme in Nicaragua. in: Mitlin D, Satterthwaite D (eds), Empowering Squatter Citizen: Local Government, Civil Society, and Urban Poverty Reduction. Earthscan, London.

Naumov V, Angelstam P, Elbakidze M. 2016. Barriers and bridges for intensifi.pdf. For Policy Econ 66: 1-10.

Potkány M, Gejdoš M, Debnár M. 2018. Sustainable innovation approach for wood quality evaluation in green business. Sustainability (Switzerland) 10 (9): 1-14. DOI: 10.3390/su10092984

Rodrigues JFD, Moran D, Wood R, Behrens P. 2018. Uncertainty of consumption-based carbon accounts. Environ Sci Technol 52 (13): 7577-7586. DOI: 10.1021/acs.est.8b00632

Roe D, Elliott J. 2006. Pro-poor conservation: the elusive win-win for conservation and poverty reduction? Policy Matters 14: 53-63.

Rowell RM. 2014. The use of biomass to produce bio-based composites and building materials. In: Waldron KW (ed.) Advances in Biorefineries: Biomass and Waste Supply Chain Exploitation. Woodhead Publishing Limited, Sawston, UK. DOI: 10.1533/9780857097385.2.803

Spelter H, McKeever DB. 1978. Wood usage trends in the furniture and fixtures industry. For Serv FPL-0239: 1-12.

Suter F, Steubing B, Hellweg S. 2017. Life cycle impacts and benefits of wood along the value chain: The Case of Switzerland. J Ind Ecol 21 (4): 874-886. DOI: $10.1111 /$ jiec. 12486

Thonemann N, Schumann M. 2018. Environmental impacts of woodbased products under consideration of cascade utilization: A systematic literature review. J Cleaner Prod 172: 4181-4188. DOI: 10.1016/j.jclepro.2016.12.069

Tian M, Li L, Wan L, Liu J, Jong W De. 2017. Forest products trade, wood consumption and forest conservation-the case of 61 countries. J Sustain For. DOI: 10.1080/10549811.2017.1356736

USDA Forest Service, FPL. 2010. Wood Handbook: Wood as an Engineering Material. Madison, WI. DOI: 10.2737/FPL-GTR-190

Wenker JL, Richter K, Rüter S. 2017. A methodical approach for systematic life cycle assessment of wood-based furniture. J Ind Ecol. DOI: $10.1111 /$ jiec.12581. 